\title{
PERLINDUNGAN HUKUM KONSUMEN BAGI SUPORTER SEPAK BOLA BERTIKET YANG DITOLAK MASUK STADION
}

\author{
Muchamad Arif Agung Nugroho \\ Fakultas Hukum Universitas Wahid Hasyim \\ agungnugroho@unwahas.ac.id
}

\begin{abstract}
ABSTRAK
Adanya kasus penolakan terhadap suporter sepak bola ke dalam stadion padahal mereka sudah memegang tiket resmi menggugat untuk mengkajinya dari sisi perlindungan hukum konsumen. Kasus-kasus demikian tidak pernah ada kelanjutannya sehingga tidak jelas bagaimana perlindungan hukum konsumen bagi suporter sepak bola. Maka dari itulah, penelitian ini menitikberatkan pada perlindungan hukum konsumen bagi suporter sepak bola bertiket yang dilarang masuk ke dalam stadion dengan tujuan memberi gambaran bagi supoter bagaimana cara menuntut hak-haknya sebagai konsumen. Penelitian ini menggunakan metode penelitian hukum normatif, yaitu memandang hukum sebagai seperangkat aturan yang tertulis. Adapun hasil penelitian ini adalah ditemukan ada dua aspek perlindungan hukum bagi suporter, yaitu aspek pidana dan aspek hukum perdata. Dari aspek hukum pidana, suporter dapat menuntut secara pidana terhadap pihak penyelenggara pertandingan sepak bola dengan dasar Pasal 62 ayat (1) UU Perlindungan Konsumen. Sedangkan dari aspek hukum perdata, suporter dapat mengajukan gugatan perbuatan melanggar hukum dalam rangka menuntut ganti rugi.
\end{abstract}

Kata Kunci: suporter sepak bola, hukum perlindungan konsumen.

\section{A. Pendahuluan}

Di Indonesia, seringkali terjadi kasus di mana suporter sepak bola ditolak masuk stadion padahal mereka telah memiliki tiket dengan alasan kapasitas stadion sudang penuh. Beberapa kejadian tersebut yang pernah diberitakan oleh media massa daring (dalam jaringan / online) antara lain adalah:

1. jabar.tribunnews.com, Waduh, Sejumlah Penonton Persib Teriak Mencari Panpel karena Ditolak Masuk Meski Punya Tiket, 13 Februari 2016. Berikut kutipan beritanya: 
Sejumlah pemilik tiket pertandingan persahabatan Persib Bandung kontra Bali United tak bisa masuk ke dalam Stadion Siliwangi, Kota Bandung, Jawa Barat, Sabtu (13/2/2016) malam. Meski membawa tiket resmi mereka tak kebagian tempat duduk dan tak diperbolehkan masuk ke dalam stadion. ${ }^{69}$

2. www.jpnn.com, Ribuan Suporter Ditolak Masuk ke Pakansari, Panas! Begini Jadinya ..., 14 Oktober 2016. Berikut kutipan beritanya:

Suasana di pintu masuk Stadion Pakansari sempat memanas jelang laga PS TNI kontra Persija Jakarta di Stadion Pakansari, Bogor, Jumat (14/10) petang. Penyebabnya, ribuan suporter bertiket, ditolak masuk ke dalam area ring road stadion. ${ }^{70}$

3. www.jawapos.com, Ratusan Suporter Pemegang Tiket Asli Ditolak Masuk Stadion Pakansari, 14 Desember 2016. Berikut kutipan beritanya:

Pihak panitia pelaksana pertandingan leg pertama final Piala AFF 2016 kembali mendapat sorotan. Pasalnya, ratusan suporter pemegang tiket asli justru ditolak masuk Stadion Pakansari oleh petugas dengan alasan sudah penuh. ${ }^{71}$

4. www.ligaolahraga.com, Bobotoh Kritisi Kesiapan Panpel Perserang Saat Menjamu Persib, 2 Maret 2018. Berikut kutipan beritanya:

Ruly sendiri mengaku dirinya senang melihat animo membara semua suporter yang hadir. Tetapi dia juga menyayangkan sikap panitia yang kurang profesional guna menggelar laga eksebisi ini. Sebab banyak yang tidak bisa masuk meski sudah memiliki tiket. $^{72}$

\footnotetext{
69 http://jabar.tribunnews.com/2016/02/13/waduh-sejumlah-penonton-persib-teriak-mencaripanpel-karena-ditolak-masuk-meski-punya-tiket

${ }_{70}^{70}$ https://www.jpnn.com/news/ribuan-suporter-ditolak-masuk-ke-pakansari-panas-begini-jadinya 71 https://www.jawapos.com/sepak-bola/sepak-bola-indonesia/14/12/2016/ratusan-suporterpemegang-tiket-asli-ditolak-masuk-stadion-pakansari

72 https://www.ligaolahraga.com/bola/bobotoh-kritisi-kesiapan-panpel-perserang-saat-menjamupersib
} 
Itulah secuil kisah suporter sepak bola bertiket yang ditolak masuk stadion oleh pihak penyelenggara yang diberitakan oleh media massa daring dan masih banyak lagi kisah-kisah serupa yang tidak terekspos.

Kalau dilihat dari sisi hukum perlindungan konsumen, suporter sepak bola bertiket termasuk kategori konsumen. Pengertian konsumen menurut Pasal 1 angka 2 UU Perlindungan Konsumen ${ }^{73}$ adalah sebagai berikut:

\section{Pasal 1}

Dalam undang-undang ini yang dimaksud dengan:

2. Konsumen adalah setiap orang pemakai barang dan/atau jasa yang tersedia dalam masyarakat, baik bagi kepentingan diri sendiri, keluarga, orang lain maupun makhluk hidup lain dan tidak untuk diperdagangkan.

Dari pengertian konsumen menurut pasal tersebut, maka disimpulkan bahwa unsur-unsur konsumen adalah sebagai berikut:

a. Setiap orang pemakai

Orang di sini diartikan sebagai subjek hukum perdata yang biasa diistilahkan dengan kata persoon. Sebagai subjek hukum, orang dapat melakukan perbuatan hukum perdata salah satunya berupa melakukan jual beli. Artinya orang sebagai subjek hukum perdata yang mana sering kali melakukan perbuatan hukum perdata berupa jual beli harus dilindungi oleh undang-undang, maka dari itulah pengertian konsumen yang ada di dalam UU Perlindungan Konsumen mencantumkan kata "orang" sebagai salah satu unsurnya. Pengertian orang di sini bisa diartikan orang perorangan yang terdiri dari seorang atau lebih. Jika lebih atau terdiri dari beberapa orang, maka tiap-tiap orang tersebut berdiri sendiri sebagai satu subjek hukum perdata. ${ }^{74}$

b. Barang dan/atau jasa

\footnotetext{
${ }^{73}$ UndanG-undang Nomor 8 Tahun 1999 Tentang Perlindungan Konsumen.

${ }^{74}$ Abd. Haris Hamid, 2017, Hukum Perlindungan Konsumen Indonesia, Makassar: Sah Media, Hal 33.
} 
Pengertian barang dan jasa menurut Pasal 1 angka 4 dan 5 UU Perlindungan Konsumen adalah sebagai berikut:

\section{Pasal 1}

Dalam undang-undang ini yang dimaksud dengan:

4. Barang adalah setiap benda baik berwujud maupun tidak berwujud, baik bergerak maupun tidak bergerak, dapat dihabiskan maupun tidak dapat dihabiskan, yang dapat untuk diperdagangkan, dipakai, dipergunakan, atau dimanfaatkan oleh konsumen.

5. Jasa adalah setiap layanan yang berbentuk pekerjaan atau prestasi yang disediakan bagi masyarakat untuk dimanfaatkan oleh konsumen.

Berdasarkan pengertian barang dan jasa tersebut, maka tontonan pertandingan sepak bola dapat dikategorikan atau memenuhi unsur-unsur sebagai barang. Apalagi sebelum menonton, suporter sepak bola diwajibkan memiliki tiket yang mana tiket itu termasuk barang yang berwujud.

c. Yang tersedia dalam masyarakat

Tiket dan tontonan sepak bola disediakan oleh penyelenggara pertandingan. Tiket tersebut secara luas dan terbuka dijual kepada masyarakat umum oleh penyelenggara pertandingan. Suporter sepak bola merupakan bagian dari masyarakat secara bebas boleh membelinya atau tidak. Jika membeli maka sudah seharusnya memiliki hak untuk masuk ke dalam stadion dan menonton sepak bola secara langsung dengan mata kepalanya sendiri, jika tidak memiliki tiket maka tidak berhak untuk masuk ke dalam stadion apalagi menontonnya. Artinya tiket dan tontonan pertandingan sepak bola merupakan suatu barang yang tersedia di masyarakat.

d. Bagi kepentingan diri sendiri, keluarga, orang lain, makhluk hidup lain

Pembeli tiket memiliki kepentingan supaya bisa masuk ke dalam stadion dan menonton pertandingan sepak bola secara langsung. Pembeli langsung belum tentu memiliki kepentingan langsung, karena bisa juga tiket tersebut dibeli untuk kepentingan pihak lain seperti keluaga, anggota kelompok suporternya, atau makhluk hidup lainnya. Jadi kata-kata "keluarga, orang lain, makhluk hidup lain" dalam unsur dimaksudkan sebagai perluasan karena faktanya pembeli langsung 
belum tentu memiliki kepentingan langsung. Namun demikian, siapapun yang memegang tiket pasti memiliki kepentingan bagi diri sendiri maupun pihak lain untuk masuk ke dalam stadion dan menonton pertandingan langsung.

e. Barang dan/atau jasa itu tidak diperdagangkan

Kata-kata "tidak diperdagangkan" menunjukkan bahwa suporter sepak bola yang memegang tiket merupakan konsumen akhir dan bukan konsumen antara, yaitu pemakai/penikmat akhir dan/atau tidak diperjualbelikan lagi. Dengan pengertian tersebut, UU Perlindungan Konsumen hanya diperuntukkan bagi konsumen akhir. ${ }^{75}$

Berdasarkan uraian unsur-unsur di atas, maka sudah sangat jelas bahwa suporter sepak bola yang membeli tiket merupakan konsumen yang wajib dilindungi oleh UU Perlindungan Konsumen. Dengan banyaknya kejadian di mana suporter sepak bola bertiket yang ditolak masuk stadion, maka perlu dilakukan kajian mendalam mengenai perlindungan hukumnya, agar ke depannya para suporter yang dirugikan bisa mendapatkan perlindungan hukum konsumen bagi dirinya. Maka dari itu, tulisan ini membahasnya dan diberi judul Perlindungan Hukum Konsumen bagi Suporter Sepak Bola Bertiket yang Ditolak Masuk Stadion.

Agar penelitian menjadi terarah dan fokus, maka ditentukan pembatasan masalah sebagai berikut:

1. Bagaimana perlindungan hukum konsumen bagi suporter sepak bola bertiket yang ditolak masuk stadion dari aspek hukum pidana?

2. Bagaimana perlindungan hukum konsumen bagi suporter sepak bola bertiket yang ditolak masuk stadion dari aspek hukum perdata?

\section{B. Metode Penelitian}

Metode penelitian yang dipakai adalah metode penelitian hukum normatif yang mana titik kajiannya terletak pada hukum tertulis, ${ }^{76}$ sehingga metode ini

\footnotetext{
75 Yusuf Shofie, 2008, Kapita Selekta Hukum Perlindungan Konsumen di Indonesia, Bandung: Citra Aditya Bakti, Hal 40.

${ }^{76}$ Johnny Ibrahim, 2006, Teori dan Metodologi Penelitiah Hukum Normatif, Malang: Bayumedia Publishing, Hal 296.
} 
memandang hukum sebagai norma tertulis. ${ }^{77}$ Metode pendekatan dalam penelitian ini adalah dengan cara memilih dan memilah peraturan perundang-undang khususnya yang berkaitan dengan hukum perlindungan konsumen. Sedangkan spesifikasi penelitiannya adalah deskriptif yaitu menyajikan data, keadaan atau gejala dengan sangat teliti dan hanya menyajikan objek penelitian dengan mengambil kesimpulan secara khusus. ${ }^{78}$ Data-data yang dipakai antara lain adalah peraturan perundang-undangan sebagai data primer, buku-buku dan tulisan-tulisan sebagai data sekunder terutama yang membahas hukum perlindungan konsumen.

\section{Pembahasan}

\section{Perlindungan Hukum Konsumen dari Aspek Hukum Pidana}

Berdasarkan UU Perlindungan Konsumen, pasal yang mengatur ketentuan pidana terletak pada Pasal 62 adalah sebagai berikut:

\section{Pasal 62}

(1) Pelaku usaha yang melanggar ketentuan sebagaimana dimaksud dalam Pasal 8, Pasal 9, Pasal 10, Pasal 13 ayat (2), Pasal 15, Pasal 17 ayat (1) huruf a, huruf b, huruf c,huruf e, ayat (2) dan Pasal 18 dipidana dengan pidana penjara paling lama 5 (lima) tahun atau pidana denda paling banyak Rp 2.000.000.000,00 (dua milyar rupiah).

(2) Pelaku usaha yang melanggar ketentuan sebagaimana dimaksud dalam Pasal 11, Pasal 12, Pasal 13 ayat (1), Pasal 14, Pasal 16, dan Pasal 17 ayat (1) huruf d dan huruf $f$ dipidana penjara paling lama 2 (dua) tahun atau pidana denda paling banyak Rp 500.000.000,00 (lima ratus juta rupiah).

(3) Terhadap pelanggaran yang mengakibatkan luka berat, sakit berat, cacat tetap atau kematian diberlakukan ketentuan pidana yang berlaku.

Dari sekian pasal-pasal larangan yang termuat dalam Pasal 62 di atas, yang paling pas untuk menjerat penyelenggara pertandingan sepak adalah Pasal 8 ayat (1) huruf d sebagai berikut

\footnotetext{
${ }^{77}$ Ronny Hanitijo Soemitro, 2009, Metodologi Penelitian Hukum dan Jurimetri, Jakarta: Ghalia Indonesia, Hal 14.

${ }^{78}$ Soerjono Soekanto, 1981, Pengantar Penelitian Hukum, 1981, Jakarta: UI Press, Hal 11.
} 
Pasal 8

(1) Pelaku usaha dilarang memproduksi dan/atau memperdagangkan barang dan/atau jasa yang:

d. tidak sesuai dengan kondisi, jaminan, keistimewaan atau kemanjuran sebagaimana dinyatakan dalam label, etiket atau keterangan barang dan/atau jasa tersebut.

Suporter sepak bola yang memiliki tiket tapi ditolak masuk ke dalam stadion sehingga mereka tidak bisa menonton pertandingan sepak bola secara langsung dengan mata kepalanya sendiri, dapat diartikan bahwa penyelenggara pertandingan telah memperdagangkan barang yang tidak sesuai dengan kondisi sebagaimana dinyatakan dalam etiket atau keterangan barang. Hal ini menunjukkan bahwa penyelenggara pertandingan telah melanggar Pasal 8 ayat (1) huruf d UU Perlindungan Konsumen. Pelanggar Pasal 8 ayat (1) huruf d UU Perlindungan Konsumen diancam dengan ancaman pidana penjara paling lama 5 tahun atau denda paling banyak Rp 2.000.000.000,00 (dua milyar rupiah) sebagaimana tercantum dalam Pasal 62 ayat (1) UU Perlindungan Konsumen.

Langkah hukum yang dapat diambil oleh suporter sepak bola bertiket yang dilarang masuk stadion adalah melaporkan pihak penyelenggara pertandingan ke pihak kepolisian. Ada baiknya laporan tersebut dilengkapi juga dengan buktibukti dan kelengkapan data untuk memudahkan proses penyelidikan maupun penyidikan.

\section{Perlindungan Hukum Konsumen dari Aspek Hukum Perdata}

Ada dua hal yang biasa dijadikan dasar dalam mengajukan gugatan perdata, yaitu gugatan wanprestasi dan gugatan perbuatan melanggar hukum. Adapun ciri-ciri, unsur-unsur dan perbedaan diantara keduanya adalah sebagai berikut:

a. Wanprestasi

Menurut J. Satrio ${ }^{79}$, wanprestasi adalah suatu keadaan di mana debitor tidak memenuhi janji atau tidak memenuhi janji sebagaimana semestinya yang

${ }^{79}$ J. Satrio, 1999, Hukum Jaminan, Bandung: Citra Aditya Bakti, Hal 121. 
mana semua kesalahan itu dapat ditimpakan kepadanya. Unsur-unsur wanprestasi adalah sebagai berikut:

1) Adanya perjanjian;

2) Perjanjian tersebut dilanggar;

3) Pelanggarannya berupa tidak dilaksanakannya isi perjanjian tersebut.

Berdasarkan unsur-unsur tersebut, wanprestasi berawal mula dari adanya perjanjian lalu perjanjian tersebut dilanggar dengan cara isi perjanjiannya tidak dilaksanakan atau dilaksanakan tapi tidak sebagaimana mestinya.

Dasar hukum yang dipakai dalam mengajukan gugatan wanprestasi adalah Pasal 1243 KUHPerdata yang berbunyi sebagai berikut:

Penggantian biaya, rugi dan bunga karena tidak terpenuhinya suatu perikatan, barulah mulai diwajibkan, apabila si berutang, setelah dinyatakan lalai memenuhi perikatannya, tetap melalaikannya, atau jika sesuatu yang harus diberikan atau dibuatnya, hanya dapat diberikan atau dibuat dalam tenggang waktu yang telah dilampaukannya. ${ }^{80}$

Berdasarkan pasal tersebut, pihak yang telah melakukan wanprestasi selain bisa dimintai penggantian biaya dapat juga dimintai ganti rugi dan juga bunga-bunga akibat wanprestasinya.

b. Perbuatan Melanggar Hukum

Menurut Munir Fuady ${ }^{81}$, perbuatan melanggar hukum adalah kumpulan dari beberapa prinsip hukum yang dimaksudkan untuk mengatur atau mengontrol perilaku bahaya, serta memberi tanggung jawab atas kerugian akibat dari pergaulan sosial, dan juga untuk memberi ganti rugi kepada korban.

Dasar hukum untuk mengajukan gugatan perbuatan melanggar hukum adalah Pasal 1365 KUHPerdata yang berbunyi sebagai berikut: Tiap perbuatan melanggar hukum, yang membawa kerugian kepada seorang lain, mewajibkan orang yang karena salahnya menerbitkan kerugian itu, mengganti kerugian

\footnotetext{
${ }^{80}$ R. Subekti dan R. Tjitrosudibio, 2003, Terjemahan: Bergerlijk Wetboek $=$ Kitab Undang undang Hukum Perdata, Jakarta: Pradnya Paramita, Hal 324.

${ }^{81}$ Munir Fuady, 2013, Perbuatan Melawan Hukum: Pendekatan Kontemporer, Bandung: Citra Aditya Bakti, Hal 4.
} 
tersebut. ${ }^{82}$ Berdasarkan ketentuan pasal tersebut dapat disimpulkan bahwa unsurunsur perbuatan melanggar hukum adalah sebagai berikut:

1) Adanya perbuatan melanggar hukum;

2) Perbuatan melanggar hukum tersebut mengakibatkan kerugian pada orang lain;

3) Ada hubungan kausalitas antara perbuatan melawan hukum dengan akibat kerugian;

4) Atas kerugian tersebut maka si pelanggar wajib mengganti rugi.

Berdasar uraian dua jenis gugatan perdata di atas yaitu gugatan wanprestasi dan perbuatan melanggar hukum, maka suporter sepak bola bertiket yang ditolak masuk stadion dapat memilih salah satunya mana kiranya yang paling pas menuruh kaidah hukum. Tiap-tiap jenis gugatan yang dipilih memiliki kelemahan dan konsekuensinya masing-masing yaitu sebagai berikut:

Pertama, bila suporter menggugat dengan dasar gugatan wanprestasi maka kesulitannya adalah dalam membuktikan unsur perjanjian. Memang suatu perjanjian tidak wajib dituangkan dalam bentuk tulisan namun suatu perjanjian memiliki persyaratan sahnya sebagaimana tercantum dalam Pasal 1320 KUHPerdata sebagai berikut:

Untuk sahnya suatu perjanjian diperlukan empat syarat:

1. Sepakat mereka yang mengikatkan dirinya;

2. Kecakapan untuk membuat suatu perikatan;

3. Suatu hal tertentu;

4. Suatu sebab yang halal. ${ }^{83}$

Ketika suporter membeli tiket, tidak jelas kapan kesepakatan antara suporter dengan pihak penyelenggara pertandingan dilakukan. Sehingga ada atau tidaknya suatu perjanjian antara suporter dengan pihak penyelenggara merupakan suatu yang samar. Padahal dasar untuk mengajukan gugatan wanprestasi awa mulanya harus ada perjanjian terlebih dahulu. Kalau tidak ada perjanjian, maka gugatan akan lebih tepat bila ditempuh dengan dasar gugatan perbuatan melanggar

\footnotetext{
${ }^{82}$ R. Subekti dan R. Tjitrosudibio, 2003, Terjemahan: Bergerlijk Wetboek = Kitab Undangundang Hukum Perdata, Jakarta: Pradnya Paramita, Hal 346.

${ }^{83}$ R. Subekti dan R. Tjitrosudibio, 2003, Terjemahan: Bergerlijk Wetboek $=$ Kitab Undangundang Hukum Perdata, Jakarta: Pradnya Paramita, Hal 339.
} 
hukum. Namun, gugatan perbuatan melanggar hukum juga memiliki kelemahan/kesulitannya sendiri.

Kedua, bila suporter menggugat dengan dasar gugatan perbuatan melanggar hukum maka kesulitannya adalah dalam membuktikan ada atau tidaknya kerugian dan kerugian tersebut memiliki kausalitas dengan perbuatan melanggar hukum.

Perbuatan melanggar hukum itu diawali dengan adanya perbuatan melanggar hukum oleh salah satu pihak, dalam perkara ini si pelanggar adalah pihak penyelenggara pertandingan sepak bolan. Pihak penyelenggara pertandingan telah melanggar hak suporter karena telah menolak mereka untuk masuk ke dalam stadion sehingga mengalami kerugian berupa kegagalan untuk menonton pertandingan secara langsung dengan mata kepala sendiri. Dengan argumen demikian, semakin jelas dan terang bahwa memang penyelenggara pertandingan sepak bola telah melakukan perbuatan melanggar hukum hingga menyebabkan para suporter bertiket rugi tidak bisa menonton pertandingan secara langsung.

Di muka persidangan, suporter harus mampu membuktikan kerugiannya memang berkaitan erat dengan perbuatan melanggar hukum yang dilakukan oleh pihak penyelenggara pertandingan. Suporter juga harus mampu membuktikan kerugiannya berupa apa saja, karena kerugian inilah yang menjadi sorotan hakim dalam mengambil putusan. Kerugian dalam gugatan perbuatan melanggar hukum pada umumnya yang mudah dikabulkan oleh hakim adalah kerugian yang bersifat material atau yang nyata atau biasa diartikan yang bisa dilihat secara kasat mata, sedangkan kerugian immaterial pembuktiannya sulit. Butuh pembuktian yang kuat untuk meyakinkan hakim bahwa ada hubungan kausalitas antara perbuatan melanggar hukum yang dilakukan oleh pihak penyelenggara pertandingan dengan kerugian immaterial yang diklaim oleh pihak suporter. Inilah yang menjadi kesulitan dalam menuntut kerugian immaterial dalam gugatan perbuatan melanggar hukum.

Diantara kedua jenis gugatan di atas, maka dapat disimpulkan bahwa jenis gugatan perbuatan melanggar hukum lebih pas untuk ditempuh oleh suporter daripada jenis gugatan wanprestasi. Walaupun pembuktian kerugian immaterial 
sulit dilakukan dalam proses gugatan perbuatan melanggar hukum, namun masih ada asa dalam melakukan pembuktian kerugian material. Walaupun akhirnya ganti rugi atas kerugian material nilainya kecil, karena kerugian material yang dialami suporter hanyalah sejumlah uang yang telah dikeluarkan untuk membeli tiket pertandingan sepak bola. Hal ini tidak sebanding dengan jumlah uang yang dikeluarkan bila suporter benar-benar menggugat pihak penyelenggara pertandingan ke pengadilan.

\section{Penutup}

Setelah dilakukan kajian mendalam, maka dapat ditarik kesimpulan bahwa perlindungan hukum konsumen bagi suporter sepak bola bertiket yang ditolak masuk ke dalam stadion terdiri dari dua aspek, yaitu perlindungan dari aspek hukum pidana dan perlindungan dari aspek hukum perdata. Adapun kesimpulan tiap-tiap aspek sebagai berikut

1. Dari aspek hukum pidana, suporter dapat melaporkan pihak penyelenggara pertandingan ke pihak berwajib karena telah melanggar Pasal 8 ayat (1) huruf d UU Perlindungan Konsumen dengan ancaman hukuman pidana penjara paling lama 5 tahun atau denda paling banyak Rp 2.000.000.000,00 (dua milyar rupiah) sebagaimana diatur dalam Pasal 62 ayat (1) UU Perlindungan Konsumen.

2. Dari aspek hukum perdata, suporter dapat mengajukan gugatan perbuatan melanggar hukum terhadap pihak penyelenggara pertandingan sepak bola sebagaimana diatur dalam Pasal 1365 KUHPerdata, yaitu dalam rangka menuntut ganti rugi atas kerugian yang diderita suporter baik yang bersifat material maupun immaterial. 


\section{DAFTAR PUSTAKA}

Abd. Haris Hamid, 2017, Hukum Perlindungan Konsumen Indonesia, Makassar: Sah Media.

J. Satrio, 1999, Hukum Jaminan, Bandung: Citra Aditya Bakti.

Johnny Ibrahim, 2006, Teori dan Metodologi Penelitiah Hukum Normatif, Malang: Bayumedia Publishing.

Munir Fuady, 2013, Perbuatan Melawan Hukum: Pendekatan Kontemporer, Bandung: Citra Aditya Bakti.

R. Subekti dan R. Tjitrosudibio, 2003, Terjemahan: Bergerlijk Wetboek $=$ Kitab Undang-undang Hukum Perdata, Jakarta: Pradnya Paramita.

Ronny Hanitijo Soemitro, 2009, Metodologi Penelitian Hukum dan Jurimetri, Jakarta: Ghalia Indonesia.

Soerjono Soekanto, 1981, Pengantar Penelitian Hukum, Jakarta: UI Press.

Yusuf Shofie, 2008, Kapita Selekta Hukum Perlindungan Konsumen di Indonesia, Bandung: Citra Aditya Bakti. 